\title{
Description of Student Responses Toward the Implementation of Problem-Based Learning Model in Physics Learning
}

\author{
Tanti $^{1}$, Dwi Agus Kurniawan ${ }^{2}$, Weni Sukarni ${ }^{3}$, Erika ${ }^{4}$, Roro Hoyi ${ }^{5}$ \\ UIN Sultan Thaha Saifuddin Jambi, Indonesia ${ }^{1}$, Universitas Jambi, Indonesia ${ }^{2,3,4,5}$ \\ tanti@uinjambi.ac.id ${ }^{1}$,dwiagus.k@unja.ac.id ${ }^{2}$, wenisukarni282.ws@gmail.com³, \\ erk.erikaaaaa@gmail.com ${ }^{4}$, rorohoyi3@gmail.com ${ }^{5}$
}

Received: June $14^{\text {th }}, 2020$. Revised: September $11^{\text {th }}, 2020$. Accepted: September $14^{\text {th }}, 2020$

\section{Keywords :}

Curriculum; Problem-Based

Learning Model; Physics;

Student Activenes

\begin{abstract}
In essence, the orientation of the 2013 curriculum is an increase and balance between attitudes, skills, and cognitive competencies. However, the current learning process is generally teacher-centered. so that through the use of a learning model that is following the 2013 curriculum it is expected to be able to make the learning process student-centered. This research was conducted at SMA Negeri 8 Muaro Jambi on students of class X IPA 3 which aims to determine student responses when given a Problem-Based Learning model during the physics learning process. This research uses a mixed-method with an explanatory sequential design that combines quantitative and qualitative research systematically. Quantitative data in the form of a questionnaire student responses to problembased learning model consisting of 20 statements and qualitative data in the form of interviews with students. Based on the results of the study it was found that the level of student response to the learning model was categorized quite well with a percentage of $56.5 \%$. Based on the results of the study, it was found that the use of problem-based learning models in learning physics can increase student activity and improve student skills. This can be proven by seeing the students' responses in quite a good category. Through problem-based learning model students also feel responsible for formulating, analyzing, and solving problems. So that learning physics is more meaningful for students.
\end{abstract}

\section{INTRODUCTION}

The rapid development of science and technology demands a change from the world of education. The need for services and opportunities to improve learning for students encourages the emergence of educational reform [1]. Education is one of the activities that have the main objective in preparing students to become people who have a positive contribution to society [2]. Education is an activity that plays an important role in humans because human education can change behavior and knowledge for 
the better. Education in Indonesia consists of several levels, one of which is the high school level [3]. Senior high school is the level of education that must be taken before proceeding to the next level of education to a higher level. At the secondary school level, learning various sciences which is certainly still the basis of one of the sciences studied is a Physics subject [4].

Physics is developed through the steps of observation, formulation of problems, preparation of hypotheses, testing hypotheses through experiments, drawing conclusions, and discovering theories and concepts [5]. Physics is an important subject to learn because it can help students to improve their ability to think and act scientifically. The ability is very useful for students to support every activity in solving problems that exist in everyday life and face the challenges of the times [6]. Physics learning is based on concepts that require high understanding. Thus, teachers need skills to master the class when learning takes place because sometimes teachers cannot keep up with the number of students in the class [7]. Physics education is a science of education which is one of the branches of natural education which usually underlies the progress and development of technology which is growing rapidly [8].

The success of the learning process is influenced by the quality and way of teaching a teacher. Quality teachers not only know but also have skills [9]. The curriculum is a very important tool for the success of educational goals because an appropriate curriculum will facilitate the achievement of desired educational goals and objectives [10]. The 2013 Curriculum Change is expected to be able to produce effective, productive, creative, and innovative Indonesian people through the strengthening of integrated attitudes, skills, and knowledge [11]. Learning using the 2013 curriculum is done to welcome students more interactively and can motivate students to play an active role, as well as provide opportunities for student creativity and independence following their talents, interests, and physical and psychological development of students [12]. The 2013 curriculum applies principles to continuously encourage students to be more active. So, the teacher only acts as a motivator and facilitator, but at the end of the core activity, the teacher also explains the improvement of the student's activities [13].

Physics Learning in the 2013 curriculum currently emphasizes student-oriented learning. So the teacher is expected to be able to develop the lesson plan design as well as possible so that the material can be conveyed broadly and deeply [14]. The purpose of using the learning model in learning activities so that students are more interested when teaching and learning. The selection of learning models must be adjusted to the basic competencies that must be mastered by students. Besides, the learning model chosen should be adapted to the conditions and abilities of students, learning resources, and the support capacity of the teacher and the school [15]. One of the various strategies is a problem-based learning model. Problem-based learning is a learning approach in which students work in teams to find solutions or solutions to authentic or complex problems [16].

Problem-Based Learning model is learning based on specific problems that are contextual presented to students, then solved by students. So that this learning can train students' abilities and skills in solving a problem [17]. Problem-based learning is a student-centered method that emphasizes the effectiveness of group discussion and teamwork; according to clues provided by teachers and the students' prior knowledge, the students cooperate to identify an effective solution to problems in a learning context [18]. Problem-based learning model conditions students to play an active role in building their knowledge through contextual problems [19]. In problem-based learning, students can construct independently the knowledge they learn so that students understand the material not by memorizing it but understanding the meaning of the material in-depth [20].

The characteristics of Problem-Based Learning model [21] include:

1) Learning begins with the provision of floating problems related to real-life;

2) Problems are selected according to the learning objectives;

3) Students solve problems with the authentic investigation, and students look for solutions to solve a given problem;

4) The teacher acts as a tutor and facilitator;

5) Students are responsible for obtaining varied knowledge and information, not from just one source;

6) Students present the results of problem-solving in the form of certain products. 
The results of preliminary research conducted that students' responses to physics subjects still tend to below. This is evidenced when the teacher explains the material there are some students not paying attention to the teacher, but chatting with his friends. Besides, the low response of students in receiving lessons such as students do not respond to teacher questions and some students are just silent in the learning process. When a physics teacher or physics teacher candidate does not have process skills, then when learning takes place the teacher can only explain the theory with conventional methods. So one of the factors is because teachers still apply conventional models in learning physics. The teacher factor is difficult to implement the model because students are still passive when learning takes place and the low ability and skills of students to actively participate in learning [22].

The physics learning process is still centered on the teacher, where the teacher still conveys the overall concept on the blackboard which is not by the established 2013 curriculum. This proves that teachers who have not applied the learning model according to the demands of the 2013 curriculum which include the Discovery, Inquiry, Project-Based, and Problem-Based Learning models. Problem-Based Learning model is a model that requires students to play an active role in solving problems that have the aim of making students gain experience, improving students' attitudes and science process skills. Besides, problem-Based Learning model has advantages that can provide opportunities for students to solve problems from their experiences. Therefore, the purpose of this study is to find out how students respond to problem-based learning model used in learning physics at SMAN 8 Muaro Jambi. So that it can create a more interesting learning atmosphere and students who actively participate.

\section{METHOD}

This research uses a mixed-method with an explanatory sequential design that combines quantitative and qualitative research systematically. Explanatory mixed methods designs, namely a combination of research methods that combine quantitative and qualitative research methods in sequence. The first stage uses quantitative methods in the form of data and numerical results and continued in the second stage uses qualitative methods in the form of data and text results. In this design, quantitative data and results are more important than qualitative data and results [23]. Thus, the qualitative method serves to clarify the quantitative data that has been obtained at an early stage.

An explanatory sequential mixed method design, which includes a two-phase scheme. In the first phase, the researcher gathers quantitative data and concludes the findings, and in the second, uses the results to design the qualitative part. The general purpose of this project was to collect qualitative data that would help explain in more detail the initial quantitative results and explore them in more depth. Quantitative data in the form of a questionnaire student responses to problem-based learning model consisting of 20 statements and qualitative data in the form of interviews with students [24].

The quantitative research is one type of research to examine the object of the sample used systematically, planned, and structured using data in the form of numbers. Quantitative research emphasizes the investigation of objective phenomena that are examined using quantitative research designs in the form of numbers, then the data is managed statistically, structured and the method of trial control is controlled [25]. Quantitative data collection using a survey method aims to find a general description of the characteristics of the sample. Survey method research is one type of research method by taking data in the form of written questions, not oral questions [26]. Qualitative data is used to strengthen and supplement quantitative data on problem under study. So in this study, researchers analyzed and classified questionnaire data supported by interviews that were narrated to describe the data in full [27].

The sampling technique of this study was using a purposive sampling technique. Purposive sampling is a sample that is done by taking subjects not based on strata, random, or region but based on the existence of certain objectives [28]. So that the sample of this study was only taken from one of a class of 23 students in Jambi State High School. The study used a test assessment instrument in the form of a 
questionnaire or questionnaire. The type of instrument used was the student response questionnaire adapted from the thesis. This test instrument uses a 5 point Likert scale [29]. The scale used in this attitude questionnaire instrument is a five-point Likert scale consisting of SDA "strongly disagree", DA "disagree", N "neutral", A "agree", and TA "totally agree" [30].

The choice of the five scale response was chosen because it has better or more complete response variability than the four scales to be able to express more maximal differences in respondents' attitudes The data obtained were processed and analyzed using SPSS 23 software. Likert scale positive statement consists of 5 points with the value of strongly agree is 5 , agree is 4 , neutral is 3 , disagree is 2 , and strongly disagree is 1 [31]. The Likert scale negative statement consists of 5 points with the value of strongly disagree is 5 , disagree is 4 , neutral is 3 , agree is 2 and strongly agree is 1 .

The data analysis technique used is a descriptive statistical analysis that includes being mean, mode, median, maximum, and minimum. Data were analyzed to obtain the percentage, frequency, and category of student responses. Descriptive statistics are used to analyze data by describing data that has been collected properly without intending to make conclusions that apply to the public [32]. The interview data analysis techniques regarding the use of problem-based learning models using Miles and Huberman's analysis are:

1. Collecting data is an activity to collect all information in the form of interviews and literature studies

2. Reducing data is an activity of summarizing, selecting main things, focusing on important things, and looking for themes and patterns. So that the data that has been reduced will provide a clearer picture.

3. Displaying data is an activity of presenting a set of structured information that gives the possibility of drawing conclusions and taking action.

4. Conclude/ verification is the result of research that answers the research focus based on the results of data analysis.

\section{RESULTS AND DISCUSSIONS}

The renewal of this research is to describe students' responses to physics subjects by using problembased learning model at SMA Negeri 08 Muaro Jambi. The following is a statistical description of student's responses to Problem-Base Learning model as shown in Table 1.

Table 1. Descriptive Statistics On Student Responses To Problem-Based Learning Model

\begin{tabular}{cccccccccc}
\hline Variable & Interval & Frequency & $\begin{array}{c}\text { Percentage } \\
(\boldsymbol{\%})\end{array}$ & Category & Mean & Median & Modus & Min & Max \\
\hline Problem- & $20.0-36.0$ & 0 & 0 & Very Bad & & & & & \\
Based & $36.1-52.0$ & 0 & 0 & Not Good & & & & & \\
Learning & $52.1-68.0$ & 13 & 56.5 & Quite Good & 66.1 & 66.0 & 66.0 & 50.0 & 82.0 \\
Model & $68.1-84.0$ & 10 & 43.5 & Good & & & & & \\
& $84.1-100.0$ & 0 & 0 & Very Good & & & & & \\
\hline
\end{tabular}

The interview results obtained from questions about students' responses to Physics subjects after using problem-based learning model are as follows:

Question: Do you like studying physics, if you like to explain why?

Answer : I like studying physics because by studying physics I can find out the physics of its application that we encounter a lot in everyday life

Question : Do you like learning with experiments or experiments, give reasons?

Answer : I prefer to experiment because it will better understand and increase knowledge and increase my curiosity to solve problems in learning Physics.

Question : Is problem-based learning model more interesting, give reasons?

Answer : Yes it is more interesting because learning to use problem-based learning model makes me prefer Physics and I find it easier to understand the material with the experiments given. 
The results of the analysis of student responses to Problem-Based Learning model showed an average percentage overall included in the quite good category. This shows that physics learning using ProblemBased Learning model gets positive responses from students, although some students still show poor responses. Based on the results of the interview students feel interested in learning Physics by using a model of Problem-Based Learning model because it can increase student activity by continuing to find out what is the right solution to solve problems regarding the experiments of Physics material being studied. Besides, students can connect the material learned with the phenomena that exist in the surrounding environment because the implementation of physics is often encountered in daily life.

The learning process using Problem-Based Learning model can increase student activity, students 'courage to express ideas, and ideas and improve students' science process skills in the physics learning process. So the implementation of Problem-Based Learning model provided in the learning activities will be more meaningful for students than information that is notified directly [33]. The learning approach using Problem-Based Learning model makes students active and creative in following the process of teaching and learning activities [34]. Problem-Based Learning model is one of the learning models that can shape scientific behavior. The learning process can bring students to solve, analyze, and evaluate a problem, and develop students' curiosity. This is because learning that involves the real world will make the learning process more meaningful [35].

Problem-Based Learning model makes students more active because in the learning process students are allowed to develop their thinking skills, directing students to be able to solve problems in the field of study being studied. The implementation of learning with Problem-Based Learning model in learning can improve students' scientific thinking skills and scientific attitudes, so that learning takes place effectively and efficiently, and can carry out learning [36]. Learning using Problem-Based Learning learning model has positive student responses because students feel happy with the learning being applied, students participate in the learning process well and student activity increases from each meeting. Based on the results of the first and second meetings, it was concluded that there was an increase in student learning activities in participating in learning using Problem Based Learning learning model. These activities affect the learning outcomes obtained at each meeting. And at the second meeting the student learning outcomes improved, student responses were positive to the learning [37].

The implementation of good learning can occur if the teacher and students work together in implementing the learning process so that the learning that is carried out can be successful. The success of learning activity can be seen from the increased student learning outcomes. While the use of learning models can increase student learning activities so that students feel responsible for solving problems in the learning process [38]. Based on the principles in the 2013 curriculum, which is encouraging students to play an active role starting with students observing certain phenomena, where the teacher can arouse students' curiosity about the phenomenon. So that in this curriculum the teacher only acts as a motivator and facilitator. However, at the end of the learning activity, the teacher explains to perfect the material from the learning activity. So that the material is delivered correctly and correctly [39].

Problem-Based Learning model is one such approach and emphasizes the significance of affective properties of students as well as cognitive and psychomotor properties to accomplish student achievement. Emphasize the effect of Problem-Based Learning model on attitudes, such as learning interests and curiosity. It has been indicated that Problem-Based Learning model is effective in terms of developing students' affective properties, such as attitude toward courses, desire and motivation, permanent knowledge-making, and acquiring skills like problem-solving, gathering knowledge, and doing research [40]. The main principle of Problem-Based Learning is to maximize learning through investigation, explanation, and resolution by starting with real and meaningful problems.

Problem-based learning is a learning model that presents contextual problems that stimulate students to learn. This given problem is used to bind students to curiosity about the intended learning. Problembased learning is the most significant innovation in education. Problem-Based Learning model helps to 
improve the development of lifelong learning abilities in an open, reflective, critical, and active learning mindset. Problem-Based Learning model facilitates the success of problem-based learning, communication, group work, and interpersonal skills better than other approaches. Problem-Based Learning is learning that is grounded in problems that occur in everyday life. Therefore educators are required to be able to present a problem according to an authentic and meaningful situation to students. This aims to make the learning process work well. The problem presented also needs to be made according to experience and easily recognized by students. The problem must also be related to the subject matter being taught. This situation will dictate the mental activity of students in understanding a concept, principle, and ability, in the situation or problem presented at the beginning of learning through the stages of problem-based learning.[41]

The problems that are presented in learning with problem-based learning model are problems related to everyday life so that problem-based learning model is suitable to be applied to physics learning. The use of a problem-based learning approach in teaching physics can help maintain the success of teachers to carry out an in-depth approach to learning activities and improve attitudes towards physics [42]. Problem-Based Learning model makes discussion, activities more interesting than usual discussions so that student activities are said to be active when students have carried out the phases of learning activities. Through Problem-Based Learning model, students learn in groups to understand the problems at hand. Besides, students can be actively involved in the learning carried out so that learning becomes meaningful. It is hoped that the provision of self-study opportunities and activities as widely as possible can help students understand the concepts being learned. Furthermore, the application of learning with Problem Based Learning model occurs active communication between teachers and students, students and students in discussing and exchanging opinions and communicating the results of the discussion [43].

Problem Based Learning model challenges students to learn to work together in groups to find solutions to real problems, problems are used to link curiosity, analytical skills, and student initiative to subject matter. In this learning, students will be more motivated to learn because of the encouragement of friends in their group, and students will not feel afraid to ask questions if they do not understand the material being taught because students are arranged to discuss with friends in their respective groups [44]. The advantages of Problem Based Learning learning model are that it is real with what is experienced by students and teachers, it can help students think critically and develop students' abilities to adapt new knowledge, foster student activity, strong student memory, and learning leads to student center learning. The PBL learning model is expected to help students think critically and be able to help students solve a problem given by the teacher. The effectiveness of the PBL learning model is that students are more active in thinking and students can understand the material so that the learning outcomes obtained by students can be as desired. Closely related to students being more active in thinking, this is included in the realm of cognitive, affective, and psychomotor assessment [45].

\section{CONCLUSION AND SUGGESTION}

The conclusion that the use of Problem-Based Learning model in learning physics can increase student activity and improve student skills. This can be proven by looking at the responses of students in quite a good category. Students who are trained to apply a scientific attitude during the learning process in class or conduct experiments or experiments such as collaborating, being active, thinking logically and critically, then the habit of being scientific will be applied in their social life so that students feel the benefits in physics lessons. Students who enjoy learning physics will be interested in spending more time studying physics, finding out solving physics problems, and increasing their knowledge of physics. When a student is happy in a lesson, he will increase it or take the time to study and find out about the learning. Therefore, a positive attitude in learning physics is very important. If students have this positive attitude, students will like physics lessons and can improve student learning achievement. So that learning physics is more meaningful for students with using Problem-Based Learning model. 
Description of Student Responses Toward the Implementation of Problem-Based Learning Model... Tanti, Dwi Agus Kurniawan, Weni Sukarni, Erika, Roro Hoyi

\section{REFERENCES}

[1] Syahrial, S., Asrial, A., Kurniawan, D. A., Nugroho, P., Septiasari, R., Pratama, R. A., \& Perdana, R. (2019). Increased Behavior of Students' Attitudes to Cultural Values Using the Inquiry Learning Model Assisted by Ethnoconstructivism. Journal of Educational Science and Technology (EST), 5(2): 166-175.

[2] Kurniawan, D. A., Astalini, A., Darmaji, D., \& Melsayanti, R. (2019). Students' Attitude towards Natural Sciences. International Journal of Evaluation and Research in Education, 8(3): 455-460.

[3] Astalini, A., Kurniawan, D. A., Perdana, R., \& Pathoni, H. (2019). Identifikasi Sikap Peserta Didik terhadap Mata Pelajaran Fisika di Sekolah Menengah Atas Negeri 5 Kota Jambi. UPEJ Unnes Physics Education Journal, 8(1): 34-43.

[4] Astatin, H., Mayasari, T., Huriawati, F., \& Oi, R. (2020). Vocational High School Students' Habits of Mind In Physics Material Through Discovery Learning Models. JIPF (Jurnal Ilmu Pendidikan Fisika), 5(2): 73-81.

[5] Hayati, N., Safarati, N., \& Marnita, M. (2020). Upaya Peningkatan Kemampuan Berpikir Kritis Siswa Melalui Media Pembelajaran Berbasis Problem Based Learning (PBL) Pada Materi Gerak Harmonik Sederhana Di Kelas X SMA Negeri 1 Kuala. Jurnal Edukasi Matematika dan Sains (JEMAS), l(1).

[6] Kurniawan, D. A., Perdana, R., \& Kurniawan, W. (2019). Identification attitudes of learners on physics subjects. Journal of Educational Science and Technology (EST), 5(1): 39-48.

[7] Putri, A. R., Maison, M., \& Darmaji, D. (2018). Kerjasama Dan Kekompakan Siswa Dalam Pembelajaran Fisika Di Kelas Xi Mipa Sma Negeri 3 Kota Jambi. EduFisika: Jurnal Pendidikan Fisika, 3(02): 32-40.

[8] Darmaji, D., Astalini, A., Kurniawan, D. A., \& Perdana, R. (2019). A study relationship attitude toward physics, motivation, and character discipline students senior high school, in Indonesia. International Journal of Learning and Teaching, 11(3): 99-109.

[9] Darmaji, D., Kurniawan, D. A., Suryani, A., \& Lestari, A. (2018). An Identification of Physics PreService Teachers' Science Process Skills Through Science Process Skills-Based Practicum Guidebook. Jurnal Ilmiah Pendidikan Fisika Al-Biruni, 7(2): 239-245.

[10] Agustin, E. W. (2019, June). Development of Curriculum 2013 as an Effort to Improve the Quality of Education in Indonesia. In 3rd International Conference on Current Issues in Education (ICCIE 2018). Atlantis Press.

[11] Sofyan, H., \& Komariah, K. (2016). Pembelajaran problem based learning dalam implementasi kurikulum 2013 Di SMK. Jurnal Pendidikan Vokasi, 6(3): 260-271.

[12] Azmi, M. K., Rahayu, S., \& Hikmawati, H. (2017). Pengaruh model problem based learning dengan metode eksperimen dan diskusi terhadap hasil belajar fisika ditinjau dari sikap ilmiah siswa kelas X MIPA SMA N 1 Mataram. Jurnal Pendidikan Fisika dan Teknologi, 2(2): 86-94.

[13] Supriatna, E. (2020). Penerapan Model Pembelajaran Problem Based Learning (PBL) untuk Meningkatkan Hasil Belajar Siswa. Journal of Classroom Action Research, 2(1): 15-19.

[14] Al Furqan, B., Ratnawulan, R. Darvina, Y., \& Sari, S. Y. (2019). Pengaruh Model Problem Based Learning (PBL) Berbantuan Media Animasi Terhadap Hasil Belajar Fisika Peserta Didik Pada Materi Termodinamika Dan Gelombang Mekanik Di Kelas XI MAN 2 Padang. PILLAR OF PHYSICS EDUCATION, 12(4): 697-704.

[15] Ulfah, M., Fatmah, H., \& Herlanti, Y. (2015). Penerapan Model Pembelajaran Problem Based Learning (PBL) Dipadu Metode Student Team Achievement Division (STAD) Untuk Meningkatkan Hasil Belajar Peserta Didik Kelas X IPA 4 SMA Negeri 1 Parung Tahun Ajaran 2014/2015 Pada Konsep Perubahan Lingkungan Dan Daur Ulang Limbah. Edusains, 7(2): 202208.

[16] Lubis, R. R., Irwanto, I., \& Harahap, M. Y. (2019). Increasing Learning Outcomes and Ability Critical Thinking of Students Through Application Problem Based Learning Strategies. International Journal for Educational and Vocational Studies, 1(6): 524-527.

[17] Prabowo, L. S. B., \& Sunarti, T. (2015). Penerapan Model Pembelajaran Inkuiri Pada Materi Alat Optik Untuk Meningkatkan Keterampilan Berpikir Kritis Siswa Kelas VII SMP Cendekia Sidoarjo. Jurnal Inovasi Pendidikan Fisika (jipf), 4(1): 6-11. 
[18] Luo, Y. J. (2019). The influence of problem-based learning on learning effectiveness in students' of varying learning abilities within physical education. Innovations in Education and Teaching International, 56(1): 3-13.

[19] Hartati, R. (2016). Peningkatan aspek sikap literasi sains siswa SMP melalui penerapan model problem based learning pada pembelajaran IPA terpadu. Edusains, 8(1): 90-97.

[20] Fitriani, D., Irwandi, D., \& Milama, B. (2017). Pengaruh model pembelajaran berbasis masalah terhadap kemampuan literasi sains siswa pada materi laju reaksi. Edusains, 9(2): 117-126.

[21] Harapit, S. (2018). Peranan Problem Based Learning (Pbl) Terhadap Kemampuan Pemecahan Masalah Dan Motivasi Belajar Peserta Didik. Jurnal Pendidikan Tambusai, 2(2): 912-917.

[22] Darmaji, D., Kurniawan, D. A., \& Irdianti, I. (2019). Physics Education Students' Science Process Skills. International Journal of Evaluation and Research in Education, 8(2): 293-298.

[23] Maison, M., Astalini, A., Kurniawan, D. A., \& Sholihah, L. R. (2018). Deskripsi Sikap Siswa SMA Negeri Pada Mata Pelajaran Fisika. Jurnal EDUSAINS, 10(1): 160-167.

[24] Bazrafkan, L., Hayat, A. A., Tabei, S. Z., \& Amirsalari, L. (2019). Clinical teachers as positive and negative role models: an explanatory sequential mixed method design. Journal of Medical Ethics and History of Medicine, 12(11): 1-15.

[25] Hamdi, A. S., \& Bahruddin, E. (2014). Metode Penelitian Kuantitatif Aplikasi dalam Pendidikan. Yogyakarta: Deepublish.

[26] Rukajat, A. (2018). Pendekatan Penelitian Kuantitatif. Yogyakarta: Deepublish.

[27] Jalinus, N., \& Risfendra, R. (2020). Analisis Kemampuan Pedagogi Guru SMK yang sedang Mengambil Pendidikan Profesi Guru dengan Metode Deskriptif Kuantitatif dan Metode Kualitatif. INVOTEK: Jurnal Inovasi Vokasional dan Teknologi, 20(1): 37-44.

[28] Heridiansyah, J. (2012). Pengaruh advertising terhadap pembentukan brand awareness serta dampaknya pada keputusan pembelian produk kecap pedas ABC (studi kasus pada konsumen pengguna kecap pedas abc di kota semarang). Jurnal STIE Semarang (Edisi Elektronik), 4(2): 5373.

[29] Devi, D. S. (2012). Penerapan Model Problem Base Learning (PBL) Untuk Meningkatkan Kemampuan Berpikir Kritis Peserta Didik Pada Pembelajaran IPA Kelas VII SMP Negeri 5 Sleman [Skripsi]. Yogyakarta (ID): Universitas Negeri Yogyakarta.

[30] Astalini, A., Kurniawan, D. A., \& Putri, A. D. (2018). Identifikasi sikap implikasi sosial dari IPA, ketertarikan menambah waktu belajar IPA, dan ketertarikan berkarir dibidang IPA siswa SMP sekabupaten Muaro Jambi. Tarbiyah: Jurnal Ilmiah Kependidikan, 7(2): 93-108.

[31] Hardiyanti, K., Astalini, A., \& Kurniawan, D. A. (2018). Sikap siswa terhadap mata pelajaran fisika di SMA Negeri 5 Muaro Jambi. EduFisika: Jurnal Pendidikan Fisika, 3(2): 1-12.

[32] Sugiyono. (2016). Metode Penelitian Kuantitatif, Kualitatif, dan $R \& D$. Bandung: Alfabeta.

[33] Prakasiwi, R., \& Ismanto, B. (2018). Efforts to improve scientific thinking skills through application discovery model-based learning environment around. Journal of Educational Science and Technology (EST), 1(1): 151-158.

[34] Kamaliah, C. (2020). Penerapan Pendekatan Pembelajaran Problem Based Learning Dapat Meningkatkan Hasil Belajar Pendidikan Pancasila Dan Kewarganegaraan Siswa Kelas IX MTs Negeri Kuta Baro Tahun Pelajaran 2017/2018. Jurnal Serambi Edukasi, 4(1): 8-15.

[35] Nursidik, D. (2020). Penerapan Model Problem Based Learning (PBL) Dalam Pembelajaran Menulis Teks Laporan Hasil Observasi Dan Dampaknya Terhadap Kemampuan Berpikir Kritis Peserta Didik SMPN 2 Kalipucang. Wistara: Jurnal Pendidikan Bahasa dan Sastra, 2(2): 168-182.

[36] Fitriyanti, F., Farida, F., \& Zikri, A. (2020). Peningkatan Sikap dan Kemampuan Berpikir Ilmiah Siswa Melalui Model PBL di Sekolah Dasar. Jurnal Basicedu, 4(2): 491-497.

[37] Ariani, T., \& Suanti, W. (2016). Efektivitas Penggunaan Model Pembelajaran Problem Based Learning (PBL) Pada Pembelajaran Fisika Siswa Kelas VIII SMP Negeri 2 Lubuklinggau Tahun Pelajaran 2015/2016. Jurnal Inovasi dan Pembelajaran Fisika, 3(2): 1-6.

[38] Nur, R. A., Haeruddin, H., \& Tewa, Y. (2019). Penerapan Model Pembelajaran Berbasis Masalah Untuk Meningkatkan Hasil Belajar Siswa Kelas XI IPA 1 SMAN 10 Kendari Pada Materi Asam Basa. Jurnal Pendidikan Kimia Universitas Halu Oleo, 4(2): 138-144.

[39] Parasamya, C. E., Wahyuni, A., \& Hamid, A. (2017). Upaya peningkatan hasil belajar fisika siswa melalui penerapan model pembelajaran problem based learning (PBL). Jurnal Ilmiah Mahasiswa Pendidikan Fisika, 2(1): 42-49. 
[40] Demirel, M., \& Dağyar, M. (2016). Effects of Problem-Based Learning on Attitude: A Metaanalysis Study. EURASIA Journal of Mathematics, Science and Technology Education, 12(8): 2115-2137.

[41] Suryana, N. (2020). Supervisi Klinis untuk Meningkatkan Kemampuan Guru SMK Negeri Jatiluhur Membuat Rencana Pembelajaran Berbasis Problem Based Learning (PBL). Syntax, 2(1): 67-78.

[42] Kurniawan, E., \& Sofyan, H. (2020, January). Application of problem based learning model to improve problem solving ability of student of XI science grade in chemistry. In Journal of Physics: Conference Series (Vol. 1440, No. 1, p. 012014). IOP Publishing.

[43] Wulandari, N. I., Wijayanti, A., \& Budhi, W. (2018). Efektivitas Model Pembelajaran Problem Based Learning Terhadap Hasil Belajar Ipa Ditinjau dari Kemampuan Berkomunikasi Siswa. Jurnal Pijar MIPA, 13(1): 51-55.

[44] Sari, Y., Sutrisno, S., \& Sugiyanti, S. (2020). Experimentation of Problem Based Learning (PBL) Model on Student Learning Motivation and Achievement on Circle Material. Formatif: Jurnal Ilmiah Pendidikan MIPA, 9(4): 315-324.

[45] Ramadhani, H. D. A., \& Nurlaela, L. (2019). Pengaruh Penerapan Model Pembelajaran Problem Based Learning (PBL) Terhadap Hasil Belajar Siswa Pada Mata Pelajaran Ilmu Gizi Kelas X Jasa Boga Di SMK Negeri 3 Kediri. Journal Tata Boga, 8(3): 526-532. 